\title{
Study on the ganglion cervicalis uteri of the aged rats
}

\author{
By \\ Osamu Takahashi and Kazuyo Shimai \\ Department of Anatomy, School of Medicine, Keio University, \\ Tokyo, Japan \\ (Director: Prof. T. Taniguchi)
}

\section{Introduction}

In the previous investigation $\mathrm{T}$ a $\mathrm{k} \mathrm{a} \mathrm{ha} \mathrm{sh}$ i (1960) has reported on the cells in the ganglion cervicalis uteri of the rats and mice, with particular reference to the vacuoles which arise in the cells of that ganglion. In that report it has been described that the occurrence of the vacuoles in the cells is not recognizable in the young rats and young mice, but it is for the first time noticeable in the five and more months old rats, and then the vacuoles are gradually increased, especially at the pregnant period and after the water soluble follicle hormone injection. On the contrary, when the animals were castrated, the vacuoles in the cells decreased. Moreover such changes have been observed in the previous investigation as changes of the tissue into fibers, deposition of pigment and the degeneration and contraction of the cells of ganglion cerviclais uteri.

However, in the previous investigation, the ganglion cervicalis uteri and the cells of that ganglion of the aged rats and mice were not ascertained. Similarily the reports on the ganglion cells of the aged rats and mice, especially on the vacuoles have not been published. Recently, with the progress of the clinical study for the aged mice, histological changes in the various organs of the aged mice, have been studied. $R$ a the r y et $\mathrm{Tu}$ ri a $f(1938)$ have reported on abnormal swelling of the Langerhans' island of the aged mice. A n d re w (1944) has described the degenerative atrophy of the cells and the adipose degeneration in the lobule of the pancreas of old mice. Moreover, $\mathrm{O} g$ a t a (1954) has reported on 
the senile degeneration, that occurs in advanced age, various endocrine impediments, especially the adipose degeneration in the main duct portion of the parotid gland and the degeneration atrophy in the striated tubules portion are found. Regarding abnormal swelling of Langerhans' island $\mathrm{O} g$ a $\mathrm{ta}$ (1956) has described that it is a modified phenomenon of aptyalism (senile degeneration). From the above mentioned reports, may be briefly summarized as follows, that the senile phenomena in animals are ascertainable in changes in the salivary gland and pancreas for the first time.

In the experiment by A n d r e w (1944), the rats of 700 to 1000 days were employed as material, but in Japan the average span of rat life is from 700 to 800 days, so that it is very difficult to breed for a much longer period than that.

The authors, employing healthy female rats which were reared for as long a period as possible, studied the senile phenomena, especially on the senile changes in the ganglion cervicalis uteri and in the cells of that ganglion.

\section{Material and Methods}

Eight healthy female rats of 730 to 760 days after birth, which were bred under the common condition were used. After the rats were operated on ventrotomy, the cervical portion of the uterus with enough parametorium were taken off and at the same time the pancreas and parotid glands were obtained. The parotid glands which are located at the portion above and forward the neck and near the skin, are red-bean-sized. These glands were surrounded with lymphatic glands. The materials were fixed with $96 \%$ alcohol solution and Bouin solution, embedded in paraffin and cut serially at 5 to $10 \mu$. N is s l staining, hematoxylin-eosin staining, azan staining and Gomori's chrome alum hematoxylin phloxine staining methods were employed.

\section{Original Findings}

The body weight of the rats of 730 to 760 days after birth which were bred under the same condition is 200 to $240 \mathrm{~g}$. On the abductory findings the subcutaneous adipose tissue is well developed, but organs are generally contracted. 
1) On the parotid glands.

The parotid glands macroscopically show a considerable contractive feature, and microscopically they show a contraction in the glandular cells and the vacuolization of the cytoplasm and besides, disappearance of the groups of the glandular cells and substitute adipose tissues are increased. At the striated portion the columnar epithelial cells are flattened and such changes as irregular arrangement of the nucleus in the cell, inspissation of the nucleus, enlargement of tubule and increasing or vitrification of the connective tissue around the tubule are noticeable (Figs. 1, 2).

2) On the pancreas.

In the glandular tissue in the pancreas, adipose degeneration is observable, namely, the fatty degeneration begins from the outer margin of the lobule and extends into the inner portion of the lobule. The nucleus of the glandular cell shows such degenerative changes as the contraction and heavy stainability. The excretory ducts in the lobule and blood vessels remain in the tissues which are degenerated in adiposis, but not any changes are found in the epithelial cells in the tubules. In Langerhans' island a figure which looks like on abnormal swelling is observed (Figs. 3, 4).

3) On the ganglion cervicalis uteri.

The uterus macroscopically shows a considerable contraction but not so heavy as that in the castrated female rats which were examined in the Takahas hi's previous report (1960). The ganglion cervicalis uteri of the rats is microscopically contractive, especially the increasing of the connective tissue is intensive and the margin of the ganglion is depressed, besides the formation of a split which results from segmentation of the ganglion is recognized. The cells of the ganglion cervicalis uteri become low in their stainability and show a picture of contractive and degenerative destruction. Some of the nuclei are irregular in shape. By means of the $\mathrm{Nis}$ i staining method, the stainability of $\mathrm{N}$ is s l granules becomes low and distributes unequally (Figs. 5,6). In the cells of the ganglion cervicalis uteri of rats, the number of the cells which contain the vacuoles is thought to be less than that in the rats which were injected with follicle hormone subcutaneouslly and those cells in the pregnant rats which were examined in the $\mathrm{T}$ akahashins investigation, but somewhat more than the cells in the castrated rats. The portion where the vacuoles give rise to is mostly the head of the ganglion and the next lies at the 
periphery of the ganglion.

The shape of the vacuoles is such various as drop-like, polyalveolar and monoalveolar. The vacuoles are stained clearly with $\mathrm{N}$ iss l staining, blue granular with azan stain and blue black fine granular with Go mori's method. Moreover, with Go mor i's method, blue-black fine granules (Gomori positive granules) are observable, with high magnification of the microscopy (above $1000 \times$ ), in the portions around the vacuoles and in the boundary between the polyalveolar shaped vacuoles.

\section{Discussion}

It was already described that eight healthy female rats which were bred under the same condition were 730 to 760 days after birth and weighing above $200 \mathrm{~g}$ each; when autopsy was carried out on these rats, the subcutaneous adipose tissue was well developed, while the organs generally showed a contractive figure.

1. In the parotid glands of these rats, all of the glandular cells show a contraction (degeneration into the vacuoles) and disappearance of the glandular cell group, substitute phenomenon of the adipose tissue, degeneration of the epithelial cells at the striated portion and enlargement of the glandular duct are observed. These findings are consistent with the findings on a phenomenon of senility by $\mathrm{O} g$ at a (1954) and by $\mathrm{Takiza}$ a (1952).

In the pancreas of the rats, adipose degeneration of the glandular tissue, degeneration of the glandular cells and abnormal swelling of the Langerhans' island are observed. These findings agree with the results obtained by $R$ a $t$ her y and $T$ ur ia $f(1938)$, A nd rew (1944), C a r l s on (1952), O g a t a (1956), Y o k o o (1956) and others. Namely, $R$ athery and $T u r i a f$ have reported on an abnormal swelling of Langerhans' island as a phenomenon of senility.

A n d rew, studying on the phnomenon of senility in the rats of 700 to 1000 days after birth, has described on the adipose degeneration in the lobule of the pancreas. $\mathrm{Og}$ a ta and $\mathrm{Yok}$ oo also have insisted that in phenomenon of senility or in asialia the adipose degeneration in the lobule of the pancreas and abnormai swelling of Langerhans' island are recongnizable.

From these data mentioned above, it may be thought that in the rats which are used in the authors' observation, several figures 
showing superannuation are in progress.

2. In the ganglion cerviclais uteri of the rats, generally contraction is observable, especially the disintegration and fiberformation of the ganglion and the formation of the splits are noticeable. These findings are similar to the pathological findings on the ganglion above the cervix which was reported by $\mathrm{Herzog}$ (1926), and are the same as the findings that were obtained from the $\mathrm{T}$ a k a has hi's previous castrated rats, while deposition of pigment which was observed in the portion between the ganglion cervicalis uteri of the castrated rats is not recognizable in this experiment.

The cells of the ganglion cervicalis uteri become low in their stainability and with $\mathrm{N}$ is S l staining the extent of the stainability is low and extremely uneven. A few reports on the senile phenomenon in the nerve cells have been published, and reports on the cells of the ganglion have rarely been encountered. J. L. O'Leary (1952), as a senile phenomenon in the central nervous system, has reported the desquamation of the nerve cells and the lowering of the stainability of $\mathrm{Niss} l$ granules. Similarly, in the authors' findings the stainability of $\mathrm{N}$ is $\mathrm{s}$ granules is unequal and becomes low.

As regards the deciduation of the nerve cells, in the authors' observation the number of the cells is generally decreased and the formation of the spaces is recognized, but the decided conclusion that it is a deciduous phenomenon was not possible to be found. In the ganglion cervicalis uteri, the number of the cells, which contain the vacuoles is but small, the shapes of the vacuoles are various. The contents of the vacuoles are stainable with azan stain or with Gom or i's staining method, but not with $\mathrm{N}$ is $\mathrm{s}$ l staining. With Gomori's staining method, Gomori positive granules are observable around the vacuoles and between the cells. From the results mentioned above, it is thought, that the vacuoles have rather to do with the neurosecretion than that they are accompanied by the senile phenomenon in the celis. If the vacuoles occuring in the nerve cells should spell the degeneration or contraction of the nerve cells as insisted on by $\mathrm{S}$ tor $\mathrm{z}$ and his coworker, the occurrence of numerous vacuoles should be observable in the cells of the ganglion in which the senile phenomenon started. However even in the cells of the ganglion cervicalis uteri of the castrated rats which were examined in the $\mathrm{Takahash}$ 's previous report, very few vacuoles occurred. From these points it is thought that 
the vacuoles which arise in the ganglion cells, does not mean the degeneration or contraction of the nerve cells.

The senile phenomena of the ganglion cervicalis uteri of the female rats are, as mentioned before, increasing of the connective fibers in the ganglion, disintegration of the ganglion, formation of splits, lowering in the stainability of the cells, and modification of the nuclear membrane. These findings generally are believed to be the senile phenomena of the organs, similarly in the ganglion and in the ganglion cells as well as the organs it is thought that the same phenomena are recognizable.

It is though that there is the advancement of the cell function related with neurosecretion, when numerous cells which contain the vacuoles are observable. Not any pathological changes in the ganglion or the desposition of pigment which is observed in the castrated rats, are observable in this experiment. But it is uncertain that these facts explain the incomplete phenomenon of senility or have not to do with the phenomenon of senility.

\section{Conclusion}

1. Employing the healthy female rats of 720 to 760 days after birth which wefe bred under the common condition, the author observed the senile phenomena in the parotid gland, pancreas, and ganglion cervicalis uteri.

2. On ganglion cervicalis uteri of rats, increasing of fibers, segmentation of the ganglion, formation of splits, lowering in the stainability of the ganglion cells and deformation of the nucleus were observed. These findings are thought to be a kind of the phenomena of senility.

3. The vacuoles which occured in the cells of the ganglion cervicalis uteri are not those which show a process of degeneration or contraction in the ganglion cells, but they are those which have to do with the ceil function connected with neurosecretion.

\section{Acknowledgement}

The authors are greatly indebted to Prof. Dr. T. Tanig u chi for his valuable criticism and guidance throughout the course of this investigation. 


\section{Literatures}

1. Andrew, W.: 1944. Senile changes in the pankreas of Wistarinstitute's rats and of man with special regard to the similarity of lobule and cavity formation. Amer. J. Anat., 76 : 97-127.

2. Bargmann, W.: 1949. Über die neurosekretorische Verknüpfung von Hypothalamus und Neurohypophyse. Z. Zellforsch., 34:610-634.

3. B lotevoge 1, W.: 1927. Sympathicus und Sexualzyklus. Versuch einer Histolophysiologie des Ganglion cervicale uteri. Z. mikro. anat. Forsch., 10 : 141-169.

4. Carlson, A.J. (Chiag): 1952. The thyroid, pancreatic islets, parathyroides, adrenals, thymus and pituitary. Cow dry's Problems of Ageing, 3rd. ed., 347380. The William \& Wilkins Co., Baltimore.

5. Edwin, H., Lennete and E. Scharrer: 1946. Neurosekretion IX Cytoplasmic inclusions in peripheral autonomic ganglion cells of the monkey. Anat. Rec., 94 : 85-92.

6. Ei chner, D.: 1951. Zur Frage der Neurosekretion der Ganglion des Nebennierenmarks. Z. Zellforsch., 36 : 293-297.

7. Eichner, D.: 1952. Zur Frage der Neurosekretion in den Ganglionzellen des Grenzstranges. Z. Zellforsch., 37: 247-280.

8. Ei chner, D.: 1953. Über den morphologischen Ausdruck funktioneller Beziehungen $z$ wischen Nebennierenrinde und neurosekretorischen $Z$ wischenhirnsystem der Ratte. Z. Zellforsch., 38 : 488-508.

9. G a u p p, R. jr., Freiburg, Br.: 1937. Neurosekretion des Sympathicus. Z. für gesammte Neur. u. Psy., 160: 357-360.

10. Go mor i, G.: 1943. Chrom-alum-hematoxylin-phloxin Bell. Amer. J. Path., $17: 395$.

11. Herzog, E.: 1926. Beitrag zur normalen und pathologischen Histologie des Sympathicus. Z. Neur., $108: 1-14$.

12. Herzog, E.: 1938. Zur Frage des Pigments und einer möglichen Neurosekretion in den sympathischen Ganglien. Beitr. path. Anat., 101: 390-405.

13. Hiraoka, S. and A. Imoto: 1955. Study on the stainability of the secretory substance in the hypothalamo-hypophyseal system of the dog. Arch. hist. jap., 8: $369-372$.

14. J a mes, L. O'L e a ry: 1952. Ageing in the nervous system. Cowdry's Problems of Ageing, 3rd ed., 223-238. The William \& Wilkins Co., Baltimore.

15. Lehm a n n, H. J. und H.H. St ange: 1953. Über das Vorkommen vakuolen. haltiger Ganglienzellen im Ganglion cervicale uteri trächtiger und nichtträchtiger Ratten. Z. Zellforsch., 38 : 230-236.

16. Maebara, T.: 1927. On the relation with hormone extract and contraction of the uterus after the castration. Igaku Chuo Z., 25:650 (in Japanese).

17. Mitsubayashi, R.: 1925. On the effects of the X-ray and castration on the uterus (rabbit). Igaku Chuo Z., 23: 1905 (in Japanese).

18. M ü 1 le r, H. : 1939. Zur Histologie des Ganglion nodosum bei Haustieren. Beitr. path. Anat., $103: 1-10$.

19. Og a t a, T.: 1954. On hormone in the salivary gland. Iden, $8: 29-32$ (in Japanese).

20. $\mathrm{Og}$ a t a, T.: 1956. On the changes of the endocrine glands in the aged and the rehabilitation of these organs after the effect of asialadenism J. endocr. 2: 1-6 (in Japanese).

21. R a thery, F. et J. Turiaf: 1938. Influence de la castration et des Infektions 
de Testostirone sur les ilots des Langerhans du Pancreas du cobaye. Cornt. rend. Soc. de biol., 128 : 155-156.

22. Sano, Y.: 1952. On the present situation of the study on the neurosecretion. Fundamental Med. Seitaino Kagaku, 6:3 (in Japanese).

23. Sano, Y., S. Naka gawa, K. Okuno and N. Otsuka: 1955. Histological study on the neurosecretory nucleus. I. General observations on nerve cells, nerve fibers and neurosecretory granules in Nucl. supraopticus and Nucl. paraventricularis of the dog. Arch. hist. jap., 7:631-636 (in Japanese).

24. Sano, Y., S. Nakagawa, T. I moto and M. Maeda: 1955. Histological study on the neurosecretory nucleus. II. On the relation among the Nissl substance,' Gomori substance and size of the nerve cells of Nucl. supraopticus and Nucl. paraventricularis of the dog. Arch. hist. jap., 7:637-639 (in Japanese).

25. Scharrer, E.: 1930. Über sekretorisch tätige Zellen im Thalamus von Fundulus heteroclitus L. Z. vergl. Physiol., 11:767-773.

26. Scharrer, E.: 1932. Sekretoproduction im $Z$ wischenhirn einiger Fische. $Z$. vergl. Physiol., 17: 491-509.

27. Scharrer, E.: 1933. Die Erklärung der scheinbar pathologischen Zellbilder im Nucleus supraopticus u. Nucl. paraventricularis. Z. Neur., 145: 462-481.

28. S ch a r rer, E. und R. G a u p pe: 1933. Neue Befunde am Nucleus supraopticus und Nucl. paraventricularis des Menschen. Z. Neur., 148: 766-776.

29. Scharrer, E., S. L. Pal a y and R.G. Nilges: 1945. Neurosecretion VIII. The Nissl substance in secreting nerve cells. Anat. Rec., 92: 23-31.

30. Takahashi, O.: 1960. On the formation of vacuoles in the nerve cells of the ganglion cervicalis uteri on the rat and mouse. Okajimas Fol. anat. jap., $34: 189-205,1960$.

31. Takiz a a, N.: 1954. Experimental study on the secretion in the salivary gland and its pathological observation. Naibunpitsu no tsudoi, Series 5, 166-194. (in Japanese).

32. Willi a m s, H. Maste ro: 1952. The female resproductive system. Cowdry's Problems of Aging, 3rd. ed., 651-685. The William \& Wilkins Co., Baltimore.

33. Yokoo, M.: 1956. On the effect of exstirpation of the submaxillary glands of the sxual glands and on the pancreas. Tokyo Ikadaigaku $Z$., 14 (6): 757-764 (in Japanese).

34. Yoshida, K.: 1935. On the physiologic action of the water soluble follicle hormone injection on the reproductive organ of the young female rats. Igakuchuo Z., 25: 650 (in Japanese).

35. Yoshida, K.: 1935. Changes in the rat uterine muscle at pregnant period. Igakuchuo Z., 44 : 193 (in Japanese).

\section{Explanation of figures}

Fig. 1. Disappearance of the glandular cells at the striated portion of the parotid glands.

Fig. 2. Flatly transformed epithelial cells at the striated portion of the parotid glands and the enlargement of space.

Fig. 3. Adipose degeneration in the lobule of the pancreas and the lobular duct and blood vessels remaining in the degenerated tissue.

Fig. 4. Abnormal swelling of Langerhans' island of the pancreas.

Fig. 5. Segmentation, depression and contraction of the ganglion cervicalis uteri.

Fig. 6. Contraction and space formation in the cells of the ganglion cervicalis uteri. 


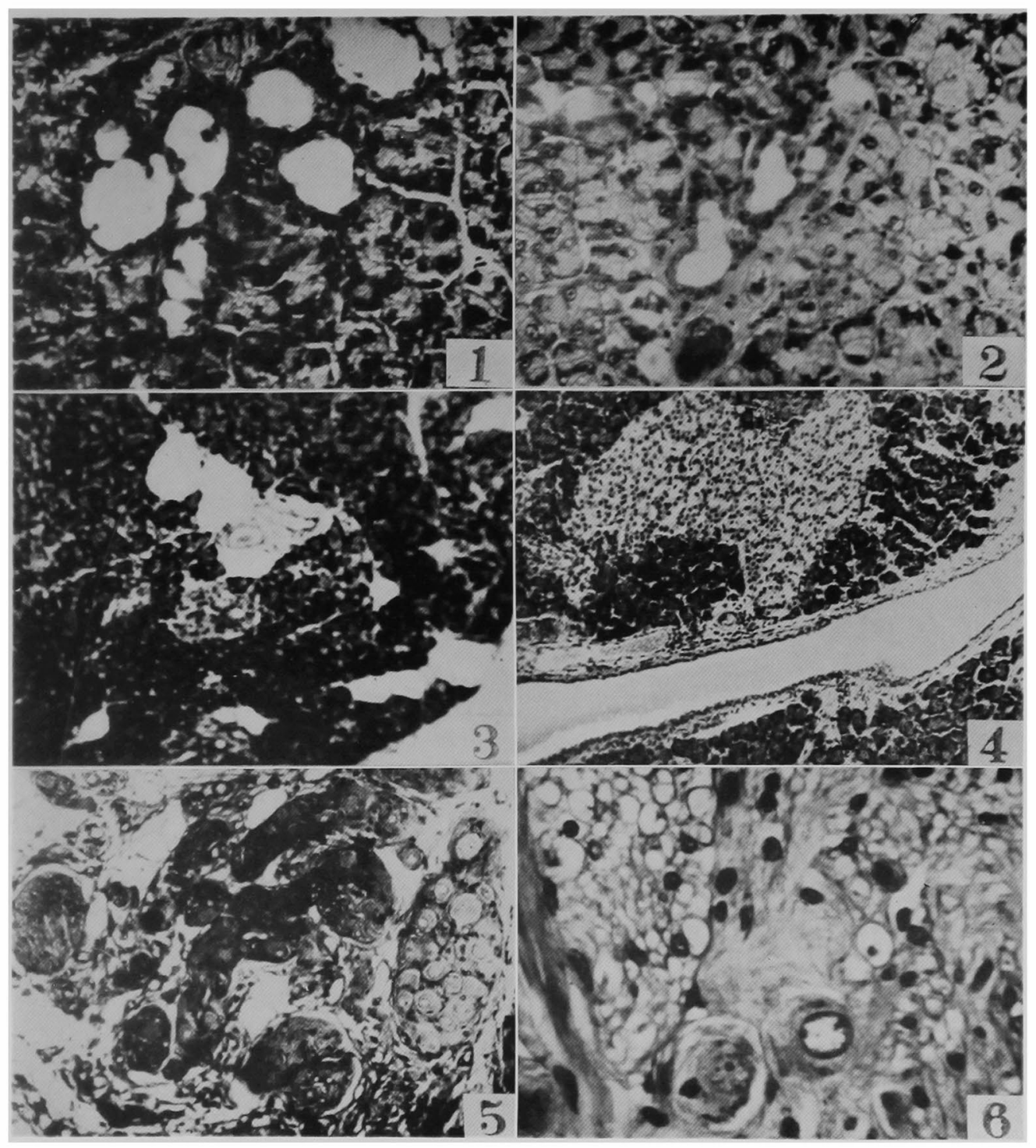

o. Takahashi and $\mathrm{K}$. Shimai 